\title{
Understanding the process of workplace psychological harassment: differences between organizational and interpersonal psychological
}

\author{
Compreendendo o processo de assédio moral no trabalho: diferenças entre \\ assédio moral organizacional e interpessoal
}

Debora Miriam Raab Glina ${ }^{1}$, Lys Esther Rocha² (in memorian)

Glina DMR, Rocha LE. Understanding the process of workplace psychological harassment: differences between organizational and interpersonal psychological / Compreendendo o processo de assédio moral no trabalho: diferenças entre assédio moral organizacional e interpessoal. Rev Med (São Paulo). 2017 jan.-mar.;96(1):1-13.

ABSTRACT: Objectives: understand workplace harassment process based on the perceptions of 64 patients examined at Occupational Health Service, Hospital das Clínicas, School of Medicine, University of São Paulo and compare organizational practices and policies and socio-demographic data associated with interpersonal and organizational psychological harassment. Method: integrated qualitative and quantitative methods, data collection between 2007 and 2012. Psychological protocol: four interviews for data collection and one consultation for orientation. Descriptive statistical analysis complemented by contingency tables between variables of interest, verifying the existence of associations by means of tests (significance level of 10\%). Results: Associations with organizational psychological harassment: aged 40-50 years, working in private companies, works overtime, no control over work pace, insufficient employees, work overload, high levels of time pressure, subjected to deadlines, inexistence of reward system, greater cognitive effort, forms of harassment - humiliation, pressure for production, discrimination/lack of equity, related to salaries and benefits. Associations with interpersonal psychological harassment: good relationship with colleagues, lack of recognition by the company, worst workstation, job layout, and tools, diagnosis unrelated to family circumstances, predominance of other forms of bullying. Conclusion: Workplace bullying is a complex and multifaceted process. The existence of two distinct phenomena was revealed: interpersonal and organizational bullying.

Keywords: Bullying/prevention \& control; Bullying/statistics \& numerical data; Workplace violence/psychology; Workplace violence/prevention \& control; Workplace/psychology; Social behavior.
RESUMO: Objetivos: compreender o processo de assédio moral no trabalho com base nas percepções de 64 pacientes avaliados no Serviço de Saúde Ocupacional do Hospital das Clínicas, Faculdade de Medicina, Universidade de São Paulo e comparar as práticas e políticas organizacionais e os dados sócio-demográficos associados ao assédio moral interpessoal e ao assédio moral organizacional. Método: integração de métodos qualitativos e quantitativos; dados coletados entre 2007 e 2012. O protocolo psicológico constituiu-se de 4 entrevistas para coleta de dados e uma consulta para orientação. Foi realizada análise estatística descritiva complementada por tabelas de contingência entre variáveis de interesse, verificando a existência de associações por meio de testes (com nível de significância de 10\%). Resultados: as associações com assédio moral organizacional foram: idade entre 40 e 50 anos, trabalho em empresas privadas, realizar horas extras, falta de controle sobre o ritmo de trabalho, número insuficiente de funcionários, sobrecarga de trabalho, altos níveis de pressão temporal, sujeito a deadlines, inexistência de um sistema de recompensas, maior exigência cognitiva, formas de assédio - humilhação, pressão por produção, discriminação/falta de equidade e relacionado a salários e benefícios. As associações com o assédio moral interpessoal foram: bom relacionamento com colegas, falta de reconhecimento pela empresa, inadequação do posto de trabalho, layout e ferramentas de trabalho, diagnostico não relacionado a circunstâncias familiares e predominância de outras formas de assédio. Conclusão: $\mathrm{O}$ assédio moral no trabalho é um processo complexo e multifacetado. A existência de dois fenômenos distintos - o assédio moral interpessoal e o assédio moral organizacional foi revelado.

Descritores: Bullying/prevenção e controle; Bullying/estatística e dados numéricos; Violência no trabalho/psicologia; Violência no trabalho/prevenção e controle; Local de trabalho/psicologia; Comportamento social.

1.Psychologist, specialist in Ergonomics, master and PhD in Social Psychology and post doctoral Researcher in Medicine. Teacher Psychiatry Institute, School of Medicine, University of São Paulo, São Paulo, Brazil.

2.Physician, specialist in Occupational Medicine, specialist in Ergonomics, Master and MD in Preventive Medicine. Professor Department of Forensic Medicine, Medical Ethics and Social and Work Medicine, School of Medicine, University of São Paulo, São Paulo, Brazil. Correspondence author: Debora Miriam Raab Glina. Alameda Ribeirão Preto 438 apartment 1501 - Bela Vista, São Paulo, SP, Brazil. CEP 01331-000. Email: deboraglina@uol.com.br 


\section{INTRODUCTION}

Ccupational Health Service (SSO), a sector of Hospital das Clínicas, School of Medicine, University of São Paulo is a tertiary attention service, located in the city of São Paulo, Brazil. Patients are referred to the service by trade unions and public health services, among others. The flow of the service includes: sorting, occupational physician, psychologist (researcher on workplace harassment), psychiatrist, and return to the occupational physician for referrals. SSO has been receiving patients suspected of being targets of harassment at work since 2006, who aim: 1) to get an expert's confirmation that they had been subjected to workplace psychological harassment (WPH); 2) to have their diseases diagnosed; 3 ) to get an expert's conclusion regarding the disease relatedness to work (specially to WPH) and 4) to discuss and receive orientation on how to cope with the situation.

In SSO the psychologist/researcher has the role of expert in WPH. According to Ege $^{1}$ in the role of expert in workplace harassment, the organizational psychologist has two tasks: 1) to make sure that it is a case of harassment at work 2) to specify the damage suffered by the person as a result of harassment.

According to Nielsen et al. ${ }^{2}$ psychological harassment, refers to the mistreatment of workers of a nonphysical nature and has been conceptualized with a wide range of labels in the scientific literature, including abusive supervision $^{3}$, incivility ${ }^{4}$, bullying/mobbing ${ }^{5}$, victimization ${ }^{6}$, interpersonal deviance ${ }^{7}$, emotional abuse ${ }^{8}$, ostracism ${ }^{9}$, and social undermining ${ }^{10}$, among others. It has been argued that this proliferation of constructs has led to a confusing state of affairs in which many scholars are studying virtually identical forms of mistreatment of subordinates and fellow workers, but with different terminology $y^{2,11,12}$. In order to avoid such proliferation, in line with Brodsky ${ }^{13}$ and Nielsen et al. ${ }^{2}$, the term workplace harassment, considered by them, a higher order construct to describe different forms of non-physical yet systematic mistreatment of and among employees, will be used throughout this article.

There is no consensual definition of WPH. There are many definitions, each of them emphasizing different aspects. Nevertheless, there are some consensual aspects that characterize WPH. According to Glina and Sobbol ${ }^{14}$, these aspects are: being a gradually evolving process composed of unwanted negative, aggressive behavior or set of behaviors, occurring frequently and persistently; which can cause harmful health effects; the existence of an imbalance in power between perpetrator and target; and intentionality. Although consensual, there are differences between the authors concerning, among others, which frequency and duration should be considered and the number of phases in the escalating process.

Liefooghe and Davey ${ }^{15}$ state that research into harassment at work generally frames the issue as an interpersonal phenomenon: harassment is something that occurs between two individuals, or between an individual and a group. Organization is viewed as the background in which interpersonal harassment occurs. In other words, organizational and work conditions are seen mainly as environmental factors that could give rise to interpersonal conflicts that can escalate into harassment ${ }^{15}$.

Einarsen et al. ${ }^{16}$ consider that one mechanism that regulates behavior in organizations is the organizational culture, which through its prevailing norms and values may both permit and even reward, harassment behaviors. Lewis and Sheehan ${ }^{17}$ argue that a culture where 'achievement of organizational goals justifies its means' (p.3) may very well foster harassment behaviors. Salin ${ }^{17}$ also argues that harassment may actually evolve out of organizational politics, that is, the deliberate use of aggression in order to improve and promote one's own interest. Triggering factors increase insecurity, thereby making it more likely for harassment processes to actually evolve. Organizational changes such as a change in management, restructuring and downsizing are examples of such factors ${ }^{7}$. Similarly, Heloani and Barreto ${ }^{19}$ consider that it is possible to point out some of the organizational situations that facilitate the emergence of violent, abusive and humiliating behaviors. These behaviors come from environments with a permissive culture and organizational climate, stimulating a disrespectful relationship between employees and encouraging complacency and complicity with the error, intentional insult and abuse. While the authors identify possible organizational causes, they nevertheless maintain the focus on the individual ${ }^{3}$.

According to Liefooghe and Davey ${ }^{15}$ in a critical sense, harassment can be attributed to the organization and its practices. This means that the organization is no longer solely regarded as the cause of interpersonal harassment or the background, but that organizational harassment is regarded as a phenomenon in itself, distinct from interpersonal issues. The authors do not deny that organizational harassment facilitates interpersonal harassment, but argue that employees use the term harassment in addition to voice their discontent regarding employee-employer relationships in the organization. Furthermore, according to them, in this context the manager ceases to be the person who is regarded as responsible.

Gosdal and Soboll ${ }^{20}$ define organizational psychological harassment as a continuum of hostilities, based on management strategy and division of labor, in order to increase productivity, reduce costs, enhance 
control, or exclude employees that the company does not want to keep. The target of the attacks is not defined, i.e., all members of the group / team are mistreated. According to Einarsen et al. ${ }^{16}$ organizational psychological harassment refers to situations in which organizational procedures and practices are perceived as oppressive, and humiliating, degrading employees so frequently and persistently that many employees feel victimized by them. Neuberger ${ }^{21}$ also identified similar situations and called them structural harassment. There is no discussion in the literature concerning the aspects that characterize this type of psychological harassment.

Given the prevalence of workplace psychological harassment worldwide, as well as its strong detrimental outcomes for those targeted (see for example, Høgh et al..$^{22}$, Nielsen et al. ${ }^{23}$ ), as well as for the organization as $\mathrm{such}^{24}$, it is fundamental to distinguish between organizational and interpersonal psychological harassment in order to plan effective preventive measures, because there is consensus in the international literature that preventive measures concerning workplace harassment can be primary, secondary and tertiary and can focus on the involved individuals, and/or work group and/or organizations (see for example the revision of the literature by Glina and Soboll ${ }^{14}$ ).

\section{Aim of the study}

The objectives of this article are: 1) to understand psychological harassment process, interpersonal psychological harassment as well as organizational psychological harassment, based on the perceptions of patients treated at SSO and 2) compare organizational practices and policies and socio-demographic data associated with interpersonal psychological harassment and organizational psychological harassment, in order to contribute to the evaluation of workplace harassment and improve prevention measures.

\section{METHOD}

\section{Design and procedure}

An action research with practical and knowledge goals embedded in the service routine of SSO was designed. This research was submitted and approved by the School of Medicine Ethical Committee.

Data collection took place between 2007 and 2012. All patients signed a term of informed consent. With the aim of integrating different approaches, this study encompassed qualitative and quantitative methods.

A protocol is a standardization of procedures. The psychological protocol developed by Debora Miriam Raab Glina, was composed of four interviews to collect data and one consultation for feedback and report correction. It was based in the protocol described in Glina and Rocha ${ }^{25}$ and Glina ${ }^{26}$.

\section{Study population}

The population consisted of 64 patients, all of them diagnosed as harassment victims, based on the following criteria: being subjected to unwanted, negative behaviors, happening at least once a week, during more than 4 months, the patient feeling helpless to defend him/herself. The existence of psychosomatic or psychiatric diseases as a consequence of WPH was not a criterion in itself to define the cases, but was important in order to understand WPH as a process. Similarly, intentionality was not a criterion to define cases, because it could only be presumed and it was not always clear. The existence of material proofs of WPH was desirable (objective harassment), but not essential in the definition of cases. Population main characteristics were: female (65.6\%), aged between 22 and 74 years, with $45.3 \%$ with 40 to 50 years, being married / living together (46.9\%), with children (71.9\%), incomplete/ complete higher education (45.3\%).

\section{Instrument}

The data collection instrument developed for this study aimed to obtain qualitative and quantitative information simultaneously. It consisted of open and closed questions and was structured in four blocks of data: socio-demographic, health and mental health, work/ job information and psychological harassment. For the purposes of this study only the variables associated to both types of harassment will be described in detail.

Socio-demographic block of data included: name, sex, age, marital status, education and children (number and ages).

Health and mental health block of data included: free complaints; symptoms of psychosomatic nature (for example: acute diseases, coronary disorders, gastrointestinal disorders, vestibular system disorders, reproductive system disorders, respiratory disorders, musculoskeletal pain, allergies, headache); and systematic exploration of signs and symptoms of psychiatric and psychological nature, by category:

- Sensorium-perceptual: quantitative changes (for example: hyperesthesia, hypoesthesia, anesthesia, analgesia, hallucinations, illusions, agnosia);

- Concepts (for example: disintegration, condensation, loss of conceptual relations)

- Judgment (for example: delusions, idea of reference, paranoid ideation); 
- Thought process/ intellectual functioning (for example: discrimination, generalization, rate, abstraction, derailing of thought, prevalent ideas, obsessive thoughts, perseveration, prolixity, incoherence, loose associations, flight of ideas);

- Memory (for example: immediate, recent, remote, retention, recall, obsessive memories, hypermnesia, hypomnesia, amnesia, paramnesia, familiarity, unfamiliarity);

- Attention (for example: distraction, distractibility, hyperprosexia, hypoprosexia, aprosexia, selective attention);

- Orientation (time and space);

- Awareness/insight (conscience) (for example: clouding of consciousness, mental confusion, twilight states, possession, trance, hypnotic state, near death experience, sleep disorders);

- Mood and affectivity (for example: hyperthimia, hypothimia, pathological joy, apathy, panic, fear, anxiety, pathological irritability, emotional tenacity, affective instability, anguish, sadness, emotional detachment, indifference, ambivalence, anomie);

- Volition, motor activity, impulse control (for example: weakness of will, abulia, hypobulia, negativism, stereotypy, impulsive acts, compulsion, self harm, impulse and suicidal act, tics, apragmatism, conversion, apraxia, psychomotor agitation, psychomotor slowness);

- Speech/ Language (spoken and written) (for example: dysarthria, dysphonia, stuttering, aphasia, agraphia, verbigeration, echolalia, slurred speech).

\section{Work information}

- Type of organization: public, private, foundation, non-governmental;

- Working time including: weekly work hours, shifts, overtime, breaks;

- Work characteristics including: work pace, control over work pace/autonomy, number of employees in the area, repetitivity, monotony, pace controlled by machine, high time pressure, submitted to deadlines;

- Human resource policies including: training, performance appraisal, reward system, career, dismissal, recognition by the organization and patient's subjective evaluation of their suitability;

- Work demands: physical, cognitive, emotional;

- Interpersonal relationships at work with: superior, colleagues, subordinates, clients, providers;

- Working conditions including: noise, illumination, temperature, vibration, exposure to chemicals, exposure to biological risks, workstation, work tools, layout, hygienic conditions and safety conditions.

- Worker's perception on the relationship between work and health impacts: health problems attributed to: harassment at work and/or bad working conditions, and/or job insecurity, and/or interpersonal relations at work, and/ or organizational changes, and/or family relations.

Workplace psychological harassment block of information. Was developed based on the content analysis of 16 initial cases, included:

\section{Forms of manifestation of workplace harassment}

- Concerning job content: job/attributions/function, including: progressive overload, sudden under load, task attribution without any training, attributions of tasks below capabilities (quantity and or quality), attribution of humiliating tasks; attributing tasks that are different from job description, attribution of employee's tasks to a trainee, prohibition to learn new tasks, prohibition for colleagues and supervisor to attribute or teach tasks to the employee;

- Concerning working place: constant transferences, transferences without previous warning, allocation in work places very distant from residence especially during sick leave, not telling the employee where is his/her working place;

$\checkmark$ Concerning work organization: sudden destruction of the previously existing work organization;

$\checkmark$ Work pressure for production and meeting deadlines: extreme time pressure, blackmails in order to increase production, impossible production goals, public display of individual productivity achievements;

$\checkmark$ Concerning working time including: prohibition to take breaks, change of shifts without consulting employee, not allowing the change of shifts between workers, forcing to do overtime;

$\checkmark$ Concerning wages, benefits, worker's rights: forcing to take vacations immediately and not according to annual planning, rejection of medical certificates, obliging to sign blank documents, obliging to write reports about mistakes which were not the employee's responsibility, obliging to accept responsibility for mistakes not made, not recognizing and not paying overwork, bad marks on performance appraisal during apprenticeship, undue diminishing in wages, demotion.

$\checkmark$ Concerning law suits: formalizing a complaint at the police station against the employee, forging evidences against the employee, withholding evidences from the employee, and disappearing 
Glina DMR, Rocha LE. Understanding the process of workplace psychological harassment.

with employee's medical file.

$\checkmark$ Ask for urgent work unnecessarily: afterwards denying request, or storing reports inside drawer.

$\checkmark$ Removal of infrastructure including: subordinates, office, work tools, etc.

$\checkmark$ Threatening termination including: menaces of dismissal during sick leave, menaces of firing for just cause, menaces of firing during apprenticeship.

$\checkmark$ Humiliations include: assigning a workplace that is a room with glass partitions for everybody to see that the employee has no tasks to do, workplace is the garbage room, ironies, jokes, ill treatment, chiding, name calling, offenses, defamation, hide worker during auditory, reprimand worker in front of colleagues, subordinates and clients.

$\checkmark$ Discriminations and lack of equity: unfair accusations, unequal treatment of employees, treat like a trainee, lack of supervisor's support.

$\checkmark$ Exclusion from courses, trainings and meetings.

$\checkmark$ Isolation includes: prohibition to talk to colleagues, e-mail blockage, being ignored during meetings.

$\checkmark$ Others include: meetings with employee's subordinates behind his/her back, occultation and withholding information, intentionally exosing to dangers, life threatens, sexual harassment, agreements during meetings afterwards denied, personal and professional devaluation, defamation, false/without base accusations, denigrate image, disallow in front of subordinates, plot, mislead, force to do something that will harm him/her, sabotage, prevent transference from section, etc.

\section{Aggravating circumstances}

- Employee's characteristics including: sex, age, race, and socio economic level; quality;

- Employee's performance: speed, experience, and

- Employee's stability in the job: being a civil employee, being a member of the internal committee of accident prevention and return to work after work related sickness absence.

Data entry to analyze the quantitative data was built in the Epidata program version 3.0. Double entry of information was used in order to ensure the quality.

\section{Data analysis}

Data analysis integrated qualitative and quantitative data.

Descriptive statistical analysis of the data took place. SPSS was used for the descriptive frequency. The variable work pace from moderate to intense was used as organizational psychological harassment indicator and regular to bad relationship with supervisor was used as interpersonal psychological harassment indicator. The associations of both indicators with other variables were analyzed and the tables included all associated variables, showing the differences between them. The level for significance was set to $\mathrm{p}<.01$ in the present study.

Contingency tables between variables of interest were created and the existence of association between them was verified using Fisher's exact test $\mathrm{t}^{27}$ for when variables have only two possible categories each or test of likelihood ratio $^{27}$ when the variables have more than two possible categories. Comparisons of time in the company between the categories of the variables of interest were carried out using the Mann-Whitney test ${ }^{27}$ for the case of only two categories or Kruskal-Wallis ${ }^{27}$ for more the two categories of variables of interest. The results will be presented in the following order: characterization of WPH for the population; types of harassment and percentages; and associations between indicators of each type of harassment and other variables. Some employees' testimonials were selected in order to illustrate the quantitative data and are used in the discussion.

\section{RESULTS}

\section{Characterizing WPH for the population}

Concerning mental health, the signs and symptoms of psychiatric and psychological nature (by category) that predominated were: thought process/ intellectual functioning $100 \%$, mood and affectivity $100 \%$, volition, motor activity and impulse control 100\%, memory $92.2 \%$, attention $89.1 \%$, sensorium-perception $73 \%$, judgment $62.6 \%$, orientation $50 \% .87 .6 \%$ had diagnosis in the groups of mood disorders and anxiety disorders (either isolated or combined).

Concerning work information, $59.4 \%$ of patients worked in private companies, $35.9 \%$ in public enterprises and $1.6 \%$ in the Union. The organizations belonged to various branches of economic activity, with a slight predominance of public administration and defense $(14.5 \%)$, education $(11.3 \%)$, financial intermediation $(9.7 \%)$, health and social services $(9.7 \%)$, all belonging to the service sector. The average time working in the 
company was 11.38 years. $60 \%$ of employees were bluecollar workers and $40 \%$ white-collar workers. $68.8 \%$ worked overtime.

As for work characteristics predominated: fast pace $76.6 \%$, no control over work pace $76.6 \%$, insufficient number of employees in the sector $76.2 \%$, insufficient training provided by the company $75 \%$, work overload $74.2 \%$, high levels of time pressure $71 \%$, constantly submitted to deadlines $54.8 \%$. Lack of recognition by the organization was referred by $82.3 \%$.

Employees evaluated human resources policies: performance appraisal existed for $50.81 \%$, from these $74.2 \%$ referred inadequate criteria for performance appraisal; inexistence of a reward system was referred by $78.1 \%$; and inexistence of a career plan was referred by $64 \% .64 \%$ of them considered the criteria for reward unfair, $66.7 \%$ considered the career plan inadequate.

$62.5 \%$ considered bad the relationship with superior, $64.1 \%$ considered good the relationship with colleagues, $75 \%$ had clients, $75 \%$ of them considered good the relationship with clients.

For $64.1 \%$, work presented physical demands and for $95.3 \%$ cognitive demands.

Working conditions evaluated as regular and bad were: noise $75 \%$, temperature $76.5 \%$, workstation $64 \%$, layout (distribution of work spaces) $63 \%$, quality of work tools $57.1 \%$, safety conditions $52.3 \%$. Vibration did not exist for $74.6 \%$. Hygienic conditions were considered good by $57.8 \%$.

Worker's perception of the relationship between work and health impacts showed that health problems were attributed to: harassment at work $98.4 \%$, bad interpersonal relations at work $91,8 \%$, bad working conditions $55.7 \%$, job insecurity $50.8 \%$, organizational changes $41 \% .78 .3 \%$ did not attribute health problems to family relations.

Concerning workplace psychological harassment, the predominant forms of manifestation of WPH were: humiliations $90.6 \%$, discriminations and lack of equity $78.1 \%$, work pressure for production and meeting deadlines $78.1 \%$, concerning job content (job/attributions/function) $76.6 \%$, firing menaces $68.8 \%$, isolation $57.8 \%$, concerning wages, benefits, worker's rights $51.6 \%$, others $33.9 \%$.

The employees did not consider the following aspects as aggravating circumstances: employees' personal characteristics $68.9 \%$, employees' performance $51.1 \%$, and employees' stability $82 \%$.

\section{Types of WPH}

All patients (64) presented some kind of harassment. Organizational harassment predominated (Table 1).
Table 1- Targets of organizational psychological harassment, interpersonal psychological harassment and both types of harassment simultaneously

\begin{tabular}{lcc}
\hline Types of harassment & $\mathbf{N}$ & $\mathbf{\%}$ \\
\hline OPH & 49 & 76,6 \\
IPH & 40 & 62,5 \\
OPH + IPH & 30 & 46,9 \\
Population & $\mathbf{6 4}$ & $\mathbf{1 0 0 \%}$ \\
\hline
\end{tabular}

\section{Associations of organizational psychological harassment (OPH) and interpersonal psychological harassment (IPH) with other variables}

Concerning socio demographic characteristics there was association between age (40 to 50 years) and $\mathrm{OPH}$. There were no associations of socio demographic characteristics with IPH.

Concerning health and mental health there was a significant association of sensorium-perception symptoms and $\mathrm{OPH}$. There was a significant association of judgment symptoms and disorientation (temporal and spatial) with IPH (Table 2).

Concerning work information there were significant associations of $\mathrm{OPH}$ with the variables: private organizations, working long hours, no control over work pace, insufficient number of employees in the sector, work overload, high levels of time pressure, continuously subjected to deadlines, inexistence of reward system (prizes) for good performance, good relationship with clients, work that presented cognitive demands and lack of safety conditions in the workplace. The associations with IPH were: lack of recognition by the organization, good relationship with colleagues, inexistence of vibration in the workplace, inadequate workstation, poor layout (distribution of work spaces), bad quality of work tools, good hygienic conditions and health problems not attributed to family relationship (Table 2).

Concerning WPH, the forms of manifestation of harassment associated with OPH were humiliations, harassment related to production/deadlines pressure, discrimination/lack of equity, wage/benefits related harassment. The form of manifestation of WPH related with IPH was other form. As for aggravating circumstances, employee's personal characteristics showed significant association with $\mathrm{OPH}$, that is, they were not a factor. There were no aggravating circumstances associated with IPH (Table 2). 
Glina DMR, Rocha LE. Understanding the process of workplace psychological harassment.

Table 2 - Variables that showed significant associations with organizational and interpersonal psychological harassment

\begin{tabular}{|c|c|c|c|c|c|c|c|c|}
\hline \multirow{2}{*}{ Factors/variables } & \multicolumn{2}{|c|}{ Total } & \multicolumn{3}{|c|}{ OPH } & \multicolumn{3}{|c|}{ IPH } \\
\hline & $\mathbf{N}$ & $\%$ & $\mathbf{N}$ & $\%$ & $\mathbf{P}$ & $\mathbf{N}$ & $\%$ & $\mathbf{P}$ \\
\hline \multicolumn{9}{|l|}{ Socio demographic } \\
\hline \multicolumn{9}{|l|}{ Age group } \\
\hline$<40$ years & 22 & 34.4 & 17 & 34,7 & \multirow{3}{*}{0.052} & 14 & 35 & \multirow{3}{*}{0.913} \\
\hline 40 to 50 years & 30 & 46.9 & 26 & 53,1 & & 18 & 45 & \\
\hline$>50$ years & 12 & 18.8 & 6 & 12,2 & & 8 & 20 & \\
\hline \multicolumn{9}{|c|}{ Health and mental health } \\
\hline \multicolumn{9}{|c|}{ Sensorium/perception symptoms } \\
\hline No & 17 & 27 & 6 & 12,5 & \multirow{2}{*}{$<0.001$} & 11 & 28,2 & \multirow{2}{*}{$>0.999$} \\
\hline Yes & 46 & 73 & 42 & 87,5 & & 28 & 71.8 & \\
\hline \multicolumn{9}{|l|}{ Judgment symptoms } \\
\hline No & 24 & 37.5 & 18 & 36,7 & \multirow{2}{*}{$>0.999$} & 20 & 50 & \multirow{2}{*}{0.009} \\
\hline Yes & 40 & 62.5 & 31 & 63,3 & & 20 & 50 & \\
\hline \multicolumn{9}{|c|}{$\begin{array}{l}\text { Orientation symptoms } \\
\text { (spatial and temporal) }\end{array}$} \\
\hline No & 32 & 50 & 22 & 44,9 & \multirow{2}{*}{0.237} & 15 & 37.5 & \multirow{2}{*}{0.019} \\
\hline Yes & 32 & 50 & 27 & 55,1 & & 25 & 62.5 & \\
\hline \multicolumn{9}{|l|}{ Work information } \\
\hline \multicolumn{9}{|l|}{ Organization } \\
\hline Public & 23 & 37.7 & 13 & 28,3 & \multirow{2}{*}{0.013} & 15 & 38.5 & \multirow{2}{*}{$>0.999$} \\
\hline Private & 38 & 62.3 & 33 & 71,7 & & 24 & 61.5 & \\
\hline \multicolumn{9}{|l|}{ Over time } \\
\hline No & 20 & 31.3 & 11 & 22,4 & \multirow{2}{*}{0.01} & 13 & 32.5 & م \\
\hline Yes & 44 & 68.8 & 38 & 77,6 & & 27 & 67.5 & נינקים \\
\hline Control over work & & & & & & & & \\
\hline No & 49 & 76.6 & 43 & 87,8 & 0001 & 31 & 77.5 & م000 \\
\hline Yes & 15 & 23.4 & 6 & 12,2 & -0.001 & 9 & 22.5 & -0.999 \\
\hline Number of employe & & & & & & & & \\
\hline Insufficient & 48 & 76.2 & 40 & 83,3 & 0022 & 31 & 77.5 & 0.26 \\
\hline Sufficient & 15 & 23.8 & 8 & 16,7 & 0.034 & 9 & 22.5 & 0.36 \\
\hline Work overload & & & & & & & & \\
\hline No & 15 & 24.6 & 7 & 14,9 & 0002 & 7 & 18.9 & 0225 \\
\hline Yes & 46 & 75.4 & 40 & 85,1 & $0.00 \mathrm{~S}$ & 30 & 81.1 & 0.253 \\
\hline High level of time $p$ & & & & & & & & \\
\hline No & 18 & 29 & 8 & 17 & 0091 & 12 & 31.6 & 0775 \\
\hline Yes & 44 & 71 & 39 & 83 & 0.001 & 26 & 68.4 & 0.175 \\
\hline Continuously subjec & adline & & & & & & & \\
\hline No & 28 & 45.2 & 16 & 34 & $000 ?$ & 17 & 44.7 & $>>00$ \\
\hline Yes & 34 & 54.8 & 31 & 66 & $0.00 \mathrm{~S}$ & 21 & 55.3 & 0.999 \\
\hline Existence of reward & rizes) & & & & & & & \\
\hline No & 50 & 78.1 & 35 & 71,4 & & 33 & 82.5 & \\
\hline Yes & 14 & 21.9 & 14 & 28,6 & 0.028 & 7 & 17.5 & 0.353 \\
\hline
\end{tabular}


Glina DMR, Rocha LE. Understanding the process of workplace psychological harassment.

Table 2 - Variables that showed significant associations with organizational and interpersonal psychological harassment

continuation

\begin{tabular}{|c|c|c|c|c|c|c|c|c|}
\hline \multirow{2}{*}{ Factors/variables } & \multicolumn{2}{|c|}{ Total } & \multicolumn{3}{|c|}{ OPH } & \multicolumn{3}{|c|}{ IPH } \\
\hline & $\mathbf{N}$ & $\%$ & $\mathbf{N}$ & $\%$ & $\mathbf{P}$ & $\mathbf{N}$ & $\%$ & $\mathbf{P}$ \\
\hline \multicolumn{9}{|c|}{ Recognition by organization } \\
\hline No & 51 & 82.3 & 38 & 79,2 & \multirow{2}{*}{0.429} & 35 & 92.1 & \multirow{2}{*}{0.017} \\
\hline Yes & 11 & 17.7 & 10 & 20,8 & & 3 & 7.9 & \\
\hline \multicolumn{9}{|c|}{ Relationship with colleagues } \\
\hline Good & 41 & 64.1 & 29 & 59,2 & \multirow{3}{*}{0.184} & 22 & 55 & \multirow{3}{*}{0.007} \\
\hline Reasonable & 14 & 21.9 & 13 & 26,5 & & 9 & 22.5 & \\
\hline $\mathrm{Bad}$ & 9 & 14.1 & 7 & 14,3 & & 9 & 22.5 & \\
\hline \multicolumn{9}{|l|}{ Relationship with clients } \\
\hline Good & 36 & 75 & 26 & 70,3 & \multirow{3}{*}{0.099} & 22 & 75.9 & \multirow{3}{*}{0.905} \\
\hline More or less & 8 & 16.7 & 8 & 21,6 & & 5 & 17.2 & \\
\hline $\mathrm{Bad}$ & 4 & 8.3 & 3 & 8,1 & & 2 & 6.9 & \\
\hline \multicolumn{9}{|l|}{ Cognitive work demands } \\
\hline No & 3 & 4.7 & 0 & 0 & \multirow{2}{*}{0.011} & 1 & 2.5 & \multirow{2}{*}{0.551} \\
\hline Yes & 61 & 95.3 & 49 & 100 & & 39 & 97.5 & \\
\hline \multicolumn{9}{|l|}{ Vibration } \\
\hline No & 47 & 74.6 & 36 & 75 & \multirow{2}{*}{$>0.999$} & 26 & 66.7 & \multirow{2}{*}{0.08} \\
\hline Yes & 16 & 25.4 & 12 & 25 & & 13 & 33.3 & \\
\hline \multicolumn{9}{|l|}{ Work station } \\
\hline Good & 22 & 36.1 & 16 & 34 & \multirow{3}{*}{0.634} & 9 & 23.7 & \multirow{3}{*}{0.029} \\
\hline More or less & 24 & 39.3 & 20 & 42,6 & & 17 & 44.7 & \\
\hline $\mathrm{Bad}$ & 15 & 24.6 & 11 & 23.4 & & 12 & 31.6 & \\
\hline \multicolumn{9}{|c|}{ Distribution of work spaces (layout) } \\
\hline Good & 23 & 37.7 & 17 & 36.2 & \multirow{3}{*}{0.626} & 9 & 23.1 & \multirow{3}{*}{0.005} \\
\hline More or less & 24 & 39.3 & 20 & 42.6 & & 18 & 46.2 & \\
\hline $\mathrm{Bad}$ & 14 & 23 & 10 & 21.3 & & 12 & 30.8 & \\
\hline Quality of work tools & & & & & & & & \\
\hline Good & 29 & 46 & 21 & 42.9 & & 13 & 33.3 & \\
\hline More or less & 16 & 25.4 & 13 & 26.5 & 0.632 & 13 & 33.3 & 0.028 \\
\hline $\mathrm{Bad}$ & 18 & 28.6 & 15 & 30.6 & & 13 & 33.3 & \\
\hline Hygienic conditions & & & & & & & & \\
\hline Good & 37 & 57.8 & 28 & 57.1 & & 26 & 65 & \\
\hline More or less & 6 & 9.4 & 4 & 8.2 & 0.758 & 0 & 0 & 0.002 \\
\hline $\mathrm{Bad}$ & 21 & 32.8 & 17 & 34.7 & & 14 & 35 & \\
\hline Safety conditions & & & & & & & & \\
\hline Good & 30 & 47.6 & 19 & 39.6 & & 18 & 46.2 & \\
\hline More or less & 4 & 6.3 & 3 & 6.3 & 0.051 & 1 & 2.6 & 0.231 \\
\hline $\mathrm{Bad}$ & 29 & 46 & 26 & 54.2 & & 20 & 51.3 & \\
\hline
\end{tabular}


Glina DMR, Rocha LE. Understanding the process of workplace psychological harassment.

Table 2 - Variables that showed significant associations with organizational and interpersonal psychological harassment

continuation

\begin{tabular}{|c|c|c|c|c|c|c|c|c|}
\hline \multirow{2}{*}{ Factors/variables } & \multicolumn{2}{|c|}{ Total } & \multicolumn{3}{|c|}{ OPH } & \multicolumn{3}{|c|}{ IPH } \\
\hline & $\mathbf{N}$ & $\%$ & $\mathbf{N}$ & $\%$ & $\mathbf{P}$ & $\mathbf{N}$ & $\%$ & $\mathbf{P}$ \\
\hline \multicolumn{9}{|c|}{$\begin{array}{l}\text { Health problems attributed to } \\
\text { family relationship }\end{array}$} \\
\hline No & 48 & 78.7 & 36 & 78.3 & \multirow{2}{*}{$>0.999$} & 33 & 86.8 & \multirow{2}{*}{0.059} \\
\hline Yes & 13 & 21.3 & 10 & 21.7 & & 5 & 13.2 & \\
\hline \multicolumn{9}{|c|}{ Forms of manifestation of WPH } \\
\hline \multicolumn{9}{|l|}{ Humiliations } \\
\hline No & 6 & 9.4 & 2 & 4.1 & \multirow{2}{*}{0.023} & 5 & 12.5 & \multirow{2}{*}{0.397} \\
\hline Yes & 58 & 90.6 & 47 & 95.9 & & 35 & 87.5 & \\
\hline \multicolumn{9}{|c|}{$\begin{array}{l}\text { Harassment related to } \\
\text { production/deadlines pressure }\end{array}$} \\
\hline No & 14 & 21.9 & 6 & 12.2 & \multirow{2}{*}{0.002} & 8 & 20 & \multirow{2}{*}{0.757} \\
\hline Yes & 50 & 78.1 & 43 & 87.8 & & 32 & 80 & \\
\hline \multicolumn{9}{|c|}{ Discrimination/lack of equity } \\
\hline No & 14 & 21.9 & 7 & 14.3 & \multirow{2}{*}{0.014} & 9 & 22.5 & \multirow{2}{*}{$>0.999$} \\
\hline Yes & 50 & 78.1 & 42 & 85.7 & & 31 & 77.5 & \\
\hline \multicolumn{9}{|c|}{$\begin{array}{l}\text { Wage/benefits/employees' } \\
\text { rights related harassment }\end{array}$} \\
\hline No & 31 & 48.4 & 19 & 38.8 & \multirow{2}{*}{0.007} & 18 & 45 & \multirow{2}{*}{0.607} \\
\hline Yes & 33 & 51.6 & 30 & 61.2 & & 22 & 55 & \\
\hline \multicolumn{9}{|c|}{ Other forms of harassment } \\
\hline No & 41 & 66.1 & 31 & 64.6 & \multirow{2}{*}{0.755} & 21 & 53.8 & \multirow{2}{*}{0.012} \\
\hline Yes & 21 & 33.9 & 17 & 35.4 & & 18 & 46.2 & \\
\hline \multicolumn{9}{|c|}{ Aggravating circumstances } \\
\hline \multicolumn{9}{|c|}{ Employees' characteristics } \\
\hline No & 42 & 68.9 & 36 & 78.3 & \multirow{2}{*}{0.01} & 29 & 76.3 & \multirow{2}{*}{0.154} \\
\hline Yes & 19 & 31.1 & 10 & 21.7 & & 9 & 23.7 & \\
\hline
\end{tabular}

\section{DISCUSSION}

In this study all the patients were targets of WPH, either of one of the types or of both of them, with predominance of the type OPH. Comparing the associations of organizational practices and policies and socio-demographic data with OPH and IPH made possible to discern a different pattern of associations with each type of WPH. The existence of different patterns of associations with each type of WPH proves the existence of two distinct phenomena. Explaining these patterns is fundamental to the planning of prevention strategies.

Socio demographic characteristics were not important to discern between the types of WPH, with the exception of age. The cases of harassment predominated in the age group of 40 to 50 years, and the age bracket of 40 to 50 years showed an association with $\mathrm{OPH}$, which is in accordance to $\mathrm{Ege}^{1}$, who found nearly half (48\%) of harassment victims in the age band between 41 and 50 years, while very few victims were under 30 years old.

Our data showed that the majority of patients worked in private companies mainly from the service sector. These results are in accordance to Ege's ${ }^{1}$ findings that showed more than $38 \%$ of the victims interviewed coming from the industrial goods and services sector. According to this author, a sure orientation towards profit exists in the industrial or tertiary sector, usually translated into a philosophy according to which whoever produces most gets the biggest reward. There was also an association between $\mathrm{OPH}$ and private organizations.

For all the patients, the predominant work characteristics were: working overtime, no control over work pace, insufficient number of employees in the sector, work overload, high levels of time pressure, constantly submitted to deadlines. These characteristics are descriptive of the ideology and organizational culture of excellence, 
wide spread mainly in private organizations ${ }^{28}$. This ideology implies a "coercion to human perfection", disregarding the employees' limits and variability ${ }^{29}$ (p.237), as well as the complexities and variability of the real work. According to Dejours ${ }^{30}$ real work means that unexpected events, incidents, functioning anomalies, organizational incoherencies, unpredictability related to materials, tools, machines, as well as to colleagues, supervisors, subordinates and clients, are to be expected. According to Seligmann-Silva ${ }^{28}$ the ideology of excellence reflects an organizational strategy to achieve submission to work overload directed to maximize production.

Although the ideology and organizational culture of excellence predominated for the studied population, the associations with OPH group showed that for this group they were determinant for their perception of WPH.

Human resources policies and practices can be considered instruments for the organizational strategy to achieve submission to production goals. The evaluations that predominated for the population were: inadequate criteria for performance appraisal, inexistence of a reward system, unfair criteria for rewards, and inadequate careers plan, insufficient training provided by the company associated with high physical and cognitive demands. These evaluations are consistent with the existence of a demandeffort imbalance ${ }^{31}$. According to this author stress at work is the result of a high effort in combination with a low reward obtained. Two sources of stress are distinguished: an extrinsic source, the demands of work, and an intrinsic source, workers' motivation in a demanding situation. Three dimensions of rewards are important: financial bonuses, socio-emotional rewards and status control (that is, opportunities for promotion and job insecurity). The associations of inexistence of a rewards system and high cognitive work demands with OPH group show that for this group the perception of an imbalance between effort and reward is determinant for their perception of WPH.

Furthermore, the association between $\mathrm{OPH}$ and work with high cognitive demands highlights the difficulties to achieve organizational, not always realistic goals, when you depend upon mental functions that cannot always happen in a prescribed amount of time (for example, creativity).

Forms of manifestation of WPH can be also considered instruments for the organizational strategy to achieve submission to production objectives. For the population predominated humiliations, discrimination and lack of equity, work pressure for production and meeting deadlines, concerning job content and firing menaces. In the OPH group associations occurred with humiliations, discrimination and lack of equity, work pressure for production and meeting deadlines organizational and wage/benefits/employees' rights related harassment. This probably means that for this group these forms of manifestation of WPH reflect even more an organizational strategy to increase production, in other words, obtaining production by any means available for the company. The fact that the OPH group did not consider that their personal characteristics had aggravating effects in the WPH shows that this group perceived WPH not as something personal, but as an organizational strategy. The following testimonial illustrates these aspects:

Initially I received a very basic and fast training (...) At
first I worked the 13 to 22 hours shift, and I was alone with
nobody to help and advise me. Solely I did the work that
should be done by 3 persons. I was pressed to give more
production and reduce my mistakes. I learned everything
by myself, from my mistakes. The volume of work kept
increasing. (..) I was asked to do the tasks with a 48 -hour
deadline in 24 hours, even if some tasks demanded the
action of other departments and I had to remain logged
during weekends even when there was no need to do it. I
worked long hours, I worked the mean of 30 to 40 extra
hours per month, in addition to the hours I had to work
athome to fulfill all the tasks. The performance appraisal
marks are from 1 to 4 (1 equals excellent and 4 means
employee's termination). I received a 3 , which implied
in a plan for my recovery and the demand to increase
even more my work pace in order to prove myself. The
supervisor said that I had to work more otherwise I would
be dismissed. This grade (3) resulted in wages loss. My
wages were already half of what people doing the same
tasks received.
(JCP, male, 33 years old, customer service assistant for
commercial operations).

What stand out in JCP's speech are the work overload and the pressure for production. Performance appraisal is used as a strategy to demand even more production. JCP's speech focuses on organizational matters and not interpersonal questions. No supervisor is viewed as responsible for the harassment.

For the population, lack of recognition by the organization was highly rated, but for IPH group it was determinant to their perception of WPH. According to Dejours $^{30}$ in exchange for the contribution each employee brings to the organization, he/she expects retribution. Contrary to the belief that the most important component of the retribution is material (salaries, wages, promotion), in fact is the symbolic dimension that counts more. This dimension expresses itself mainly by the recognition. Recognition as acknowledgment that the employee's contribution was received, and recognition as a sign of gratitude for the contribution. The recognition always refers to the work and not to the person. When the employee receives recognition of his work, work becomes a decisive mediator of identity construction and of health ${ }^{16}$. For the IPH group the kind of recognition that is lacking is what Dejours ${ }^{32}$ call the 'judgement of utility', which is the judgement concerning social, economic or technical utility of the employee's work, and not performance or profitability. This judgement always comes from the hierarchy and eventually from the clients. As the 
relationship with superiors was considered even worse by the IPH group, we can hypothesize that this kind of recognition was not taking place. If the organization complies with interpersonal psychological harassment, the subliminal message is that the employee is probably considered valueless and unimportant by the organization, i.e., someone who can be discarded and easily replaced. As a result, of the lack of recognition employees' subjectivity could be threatened.

A side effect of the lack of recognition by the organization could be affective negativity. The negative affectivity can be defined as a general personality trait reflecting individual differences in negative emotionality and self-concept, i.e. the employee concentrates on negative aspects of everything and experiences considerable distress in all situations. The negative affectivity may influence not only the employees' perceptions of working environment, but also their assessment of their state of health or welfare ${ }^{33}$. Although the population referred poor working conditions (noise, temperature, workstation, layout, quality of work tools), the associations of IPH with worst workstation, layout and quality of work tools shows that for IPH group these conditions were considered even worse.

The population considered the relationship with colleagues good, but it was not considered so good by the IPH group. Negative affectivity can explain this perception of a worse relationship with colleagues. Additional explanations could be the example provided by the supervisor who bullies, the "fear of dismissal" and the "fear of contamination" ${ }^{28}$ and also the increase of competition and individuality in the work places.

The population attributed health problems to: harassment at work, interpersonal relations at work, bad working conditions, job insecurity, organizational changes. Health problems were not attributed to family relations. The association of IPH with not attributing health problems to family relations is interesting. In a situation of WPH a worsening of family relations could be expected. Seligmann-Silva ${ }^{28}$ explains the loss of social and affective supports as a consequence of the dislocation of feelings of irritation, anger, sorrow, and shame to the family. This probably happens, but at the same time, family can provide social and affective support to the bullied employee. The IPH group clearly perceives that the source of the health problems is not the family, but work. The following testimonial illustrates these aspects:

I was assigned to the morning shift beginning at $5 \mathrm{~h} 30 \mathrm{~m}$, but worked 50 extra hours per week. Since I asked the supervisor not to work overtime, he increased my work volume. Daily he changed my work schedule, assigned me different buses and itineraries. He assigned me to the "heavier" itineraries, like Parelheiros - Vila Mariana, which took me 3 hours only the one-way trip. I had no time to take a break between trips. When I complained to the supervisor about this situation, he told me that in order to let me go or force me to ask for resignation, he would register all the delays and customers' complaints in my file, because as I was an excellent worker, never absent or late for work, he did not have grounds to dismiss me. He shouted at me in front of everybody. Once he assigned me to a bus with brake problems and tried to blame me. (NST, male, 40 years old, bus driver).

What stands out in NST speech is the persecution he suffered from a supervisor who is a bully and wanted to get rid of him. The focus here is on the interpersonal relation with the supervisor and not on organizational aspects. Even if he was an employee who has always presented a good performance he did not receive recognition or protection from the organization.

Concerning the strong points of this study four aspects can be cited: SSO was an important reference for the health system concerning WPH victims in the city of São Paulo and even in Brazil; the qualitative and quantitative aspects considered; the in depth data analysis, detailing all the important variables concerning work and health aspects; and the specification of types and forms of harassment and aggravating circumstances.

As for the limitations of this study three aspects can be pointed. Firstly, solely employees' directed to SSO composed the studied population. In this sense it could be considered a "biased" sample. Another aspect is that only patients from one occupational health service, i.e. SSO, were examined and they were a very heterogeneous population. The third aspect is that this study should be complemented by a detailed and deep qualitative analysis of the employees' testimonials. The authors intend to deal with the third aspect in another article.

\section{CONCLUSION}

Harassment at work is a complex and multifaceted process. This study revealed the existence of two distinct phenomena: interpersonal harassment and organizational harassment, each associated with different aspects. Understanding these phenomena is necessary because to intervene, it is necessary first of all to know. In case of $\mathrm{OPH}$, as the ideology of excellency is the determinant to employees' perception of WPH, effective preventive measures should focus in changes in work organization, with the increase in workers' participation in organizational decisions. Primary prevention focusing on the organization is suggested.

The best preventive measures in cases of IPH are increases in the recognition by the organization and improvement of interpersonal working relations, including leadership training for supervisors. Secondary and tertiary prevention focusing on the involved individuals and work group are recommended. 
Acknowledgements: To all patients who participated in the study and to Gisele Mussi coordinator of SSO, who facilitated the study, to all occupational doctors of SSO who collaborated with the research. I also recognize the help I received from the editors and reviewers in the improvement of this text.

\section{REFERENCES}

1. Ege H. La valutazione peritale del danno da mobbing. Milano: Giuffrè Editore; 2002.

2. Nielsen MB, Glasøc L, Einarsen S. Exposure to workplace harassment and the five factor model of personality: a metaanalysis. Pers Individ Dif. 2017;104:195-206. http://dx.doi. org/10.1016/j.paid.2016.08.015.

3. Tepper BJ. Abusive supervision in work organizations: review synthesis, and research agenda. J Management. 2007;33(3):261-89. Available from: http://journals.sagepub. com/doi/pdf/10.1177/0149206307300812.

4. Cortina LM, Magley VJ, Williams JH, Langhout RD. Incivility in the workplace: incidence and impact. J Occup Health Psychol. 2001;6(1):64-80. http://dx.doi.org/10.1037/10768998.6.1.64.

5. Einarsen S, Hoel H, Zapf D, Cooper CL. The concept of bullying and harassment at work: the European tradition. In: Einarsen S, Hoel H, Zapf D, Cooper CL, editors. Bullying and harassment in the workplace. Developments in theory, research, and practice. 2nd ed. Boca Raton: CRC Press; 2011. p.3-40.

6. Aquino $\mathrm{K}$, Thau S. Workplace victimization: aggression from the target's perspective. Annu Rev Psychol. 2009;60:717-41. doi: 10.1146/annurev.psych.60.110707.163703.

7. Berry CM, Ones DS, Sackett PR. Interpersonal deviance, organizational deviance, and their common correlates: a review and meta-analysis. J Appl Psychol. 2007;92(2):41024. doi: 10.1037/0021-9010.92.2.410.

8. Keashly L. Emotional abuse in the workplace: conceptual and empirical issues. J Emotional Abuse. 1998;1(1):85-117. doi: 10.1300/J135v01n01 05 .

9. Williams KD. Ostracism. Annu Rev Psychol. 2007;58:425-52. Available from: http://www15.uta.fi/arkisto/aktk/projects/sta/ Williams_2007_Ostracism.pdf.

10. Duffy MK, Ganster DC, Pagon M. Social undermining in the workplace. Acad Manage J. 2002;45(2):331-51. http://dx.doi. org/10.2307/3069350.

11. Hershcovis MS. "Incivility, social undermining, bullying ... oh my!": a call to reconcile constructs within workplace aggression research. J Org Behav. 2011;32(3):499-519. http:// dx.doi.org/10.1002/Job.689.

12. Raver JL, Barling J. Workplace aggression and conflict: Constructs, commonalities, and challenges for future inquiry. In: De Dreu CKW, Gelfand MJ, editors. The psychology of conflict and conflict management in organizations. New York: Lawrence Erlbaum Associates; 2007.

13. Brodsky CM. The harassed worker. Toronto: Lexington Books; 1976.

14. Glina DMR, Soboll LA. Intervenções em assédio moral no trabalho: uma revisão da literatura. Rev Bras Saude Ocup (São Paulo). 2012;37(126):269-83. http://dx.doi.org/10.1590/ S0303-76572012000200008.

15. Liefooghe APD, Mackenzie DK. Accounts of workplace bullying: the role of the organization. Eur J Work Org Psychol. 2001;10(4):375-92. http://dx.doi. org/10.1080/13594320143000762.

16. Einarsen S, Hoel H, Zapf D, Cooper CL. Workplace bullying: Individual pathology or organizational culture? In: Bowie $\mathrm{V}$, Fisher BS, et al., editors. Workplace violence: issues, trends, strategies. Portland: William Publishing; 2005. p.229-47.

17. Lewis D, Sheehan M. Introduction: workplace bullying: theoretical and practical approaches to a management challenge. Int J Manage Decision Making. 2003;(4):1-10. doi: 10.1081/DMR-120018245.

18. Salin D. Bullying and organizational politics in competitive and rapidly changing work environments. Int $\mathrm{J}$ Manage Decision Making. 2003;4(1):35-45. http://hdl.handle. net/10227/281.

19. Heloani JR, Barreto M. Aspectos do trabalho relacionados à saúde mental: assédio moral e violência psicológica no trabalho. In: Glina DMR, Rocha LE, organizadores. Saúde mental no trabalho: da teoria à prática. São Paulo: Roca; 2010 . p.31-48.

20. Gosdal TC, Soboll LAP. Assédio moral interpessoal e organizacional. São Paulo: LTR; 2009.

21. Neuberger O. Mobbing. Übel mitspielen in organisationen (mobbing. playing bad games in organisations). 3rd ed. Munich: Hampp; 1999.

22. Høgh A, Mikkelsen EG, Hansen ÅM. Individual consequences of workplace bullying/mobbing. In: Einarsen S, Hoel H, Zapf D, Cooper CL, editors. Bullying and harassment in the workplace. Developments in theory, research, and practice. 2nd ed. Boca Raton: CRC Press; 2011. p.107-28.

23. Nielsen MB, Indregard AM, Øverland S. Workplace bullying and sickness absence - A systematic review and meta-analysis of the research literature. Scand J Work Environ Health. 2016;42(5):359-70. doi: 10.5271/sjweh.3579.

24. Hoel H, Sheehan M, Cooper CL, Einarsen S. Organisational effects of workplace bullying. In: Einarsen S, Hoel H, Zapf $\mathrm{D}$, Cooper CL, editors. Bullying and harassment in the workplace. Developments in theory, research, and practice. 2nd ed. Boca Raton: CRC Press; 2011. p.129-48.

25. Glina DMR, Rocha LE. Protocolo de assédio moral no trabalho para pesquisas, diagnósticos e elaboração de laudos. In: Gosdal TC, Soboll LAP. Assédio moral interpessoal e organizacional. São Paulo: LTR; 2009. p.139-51.

26. Glina DMR. Assédio moral no trabalho. In: Glina DMR, Rocha LE, organizadores. Saúde mental no trabalho: da teoria à prática. São Paulo: Roca; 2010. p.427-36.

27. Kirkwood BR, Sterne JAC. Essential medical statistics. 2nd ed. Massachusetts, USA: Blackwell Science; 2006. p.502.

28. Seligmann-Silva E. Trabalho e desgaste mental: o direito de ser dono de si mesmo. São Paulo: Cortez; 2011.

29. Franco T, Druck MG, Seligmann-Silva E. As novas relações do trabalho, o desgaste mental do trabalhador e os transtornos 
Glina DMR, Rocha LE. Understanding the process of workplace psychological harassment.

mentais no trabalho precarizado. Rev Bras Saude Ocup. 2010;35(122):229-48. http://dx.doi.org/10.1590/S030376572010000200006 .

30. Dejours C. L'évaluation du travail á l'épreuve du réel: critiques des fondements de l'évaluation. Paris: Editions Quae; 2008.

31. Siegrist J, Peter R, Junge A, Cremer P, Seidl D. Low status control, high effort at work and ischemic heart disease: prospective evidence from blue-collar men. Soc Sci Med. 1990;31:1127-34. http://dx.doi.org/10.1016/02779536(90)90234-J.

Received: January 12, 2017

Accepted: February 16, 2017
32. Dejours C. Subjetividade, trabalho e ação. Rev Produção (São Paulo). 2004;14(3):27-34. http://dx.doi.org/10.1590/ S0103-65132004000300004.

33. Frese M, Zapf D. Methodological issues in the study of work stress: Objective vs. subjective measurement of work stress and the question of longitudinal studies. In: Cooper CL, Payne R. Causes, coping, and consequences of stress at work. Chichester: Wiley; 1988. p.375-411. 